\title{
Contingency Model to Increase the Uptake of Higher Education Graduates in the Job Market
}

\author{
Sri TRISNANINGSIH", Sutrisno SUTRISNO ${ }^{* *}$, Yani PERMATASARI ${ }^{* * *}$, \\ Failasuf Herman HENDRA $^{* * * *}$, Erna SULISTYOWATI ${ }^{* * * * *}$
}

Received: October 17, 2019 Revised: November 5, 2019 Accepted: February 24, 2020.

\begin{abstract}
This study investigates graduate competencies that can improve the uptake of higher education graduate outcomes in the working environment in Indonesia. This research was conducted by collecting data through sending questionnaires directly by the research team, via courier, or via postal service to respondents. A survey with questionnaire is carried out on April 2019, and the data from 117 respondents was analyzed. The sample population was all private higher education in the area of the I-XIV Higher Education Service Institution in Indonesia. This study employs factor analysis and structural equation modelling. The results show that the Graduates' competencies had a significant direct effect on the uptake of higher education graduates in the job market. The indirect effect of a Diploma Supplement and networking as mediation has a level of influence that is higher than the direct effect of graduate competence on the uptake of higher education graduate outcomes in the job market. The findings suggest that the Diploma Supplement and networking can increase the uptake of higher education graduates in Indonesia as expected by stakeholders and be able to compete in the global or international scale of environmental working. The professionalism of lecturers has a significant influence on the quality of learning.
\end{abstract}

Keywords: Higher Education Graduates Competence, Diploma Supplement, Networking, Job Market, Indonesia

JEL Classification Code: A22, I20, I21

\section{Introduction}

*First Author. Professor, Department of Accountancy, Faculty of Economics and Business, UPN "Veteran" Jawa Timur, Indonesia. Email: trisnahendrawan65@gmail.com

**Senior Lecturer, Dean, Faculty of Law, UPN “Veteran” Jawa Timur, Indonesia. Email: Sutrisno_hukum88@yahoo.com

${ }^{* * *}$ Corresponding Author. Lecturer, Department of Accountancy, Faculty of Economics and Business, Universitas Airlangga, Surabaya, Indonesia [Postal Address: Medokan Asri Tengah II Q/3, Rungkut, Surabaya, East Java, 60295, Indonesia]

Email: yanipermatasari@feb.unair.ac.id

****Lecturer, Department of Architecture, Institute Technology Adhi Tama, Surabaya, East Java, Indonesia.

Email: failasuf.herman@gmail.com

*****Lecturer, Department of Accountancy, Faculty of Economics and Business, UPN "Veteran” Jawa Timur, Indonesia.

Email: erna.sulistyowati@upnjatim.ac.id

(c) Copyright: The Author(s)

This is an Open Access article distributed under the terms of the Creative Commons Attribution Non-Commercial License (http://Creativecommons.org/licenses/by-nc/4.0/) which permits unrestricted noncommercial use, distribution, and reproduction in any medium, provided the original work is properly cited.
The labor movement between countries in the current global era is increasingly flowing, especially with the global alliance (AEC, AFTA, WTO). So that, the demands on the management and improvement of $t$ the national workforce's quality and the qualifications equality with foreign workers will be one of the biggest challenges for the development of the Indonesian economy. So far, the quality of Indonesia's human resources is still relatively behind compared to other countries even within the scope of ASEAN. This is reflected in the ranking in the Human Development Index issued by the United Nations Development Program

Based on the United Nations Development Programme's Human Development Report, last released on March 14, 2013 and compiled based on 2012 data covering 185 of 193 UN member states, it was found that the position of the Indonesian Human Development Index (HDI) compared to neighboring countries can be seen from the ranking: Singapore 9 and Brunei 30 (very high); Malaysia 62 and Sri Lanka 73 (high); Thailand 89, Indonesia 108, Philippines 117, Timor Leste 128 (intermediate). This shows that our country's human resources are still lagging behind. 
Therefore, Indonesia must try far harder than other countries in order to catch up.

Higher Education Institutions (HEIs) are place contributing to the intellectual advancement of the nation, the quality of human resource, and to a number of socioeconomic improvements for society and organizations, therefore it needs to be viewed as a long-term social investment for the promotion of economic growth, cultural development, social cohesion, equity and justice (Kumari, 2014; Le \& Nguyen, 2018). Moreover, higher education as an agent in the development of human resources must become the pioneer in the development of higher education curriculum in order to enhance the quality of university graduates and have high competitiveness. Therefore, the development of higher education curriculum must always be refined. Quality standards of competence as learning outcomes must be well established so that the quality of human resources produced from higher education can be more accountable.

The government policy on Indonesian Qualification Framework (IQF) is a reference for the structuring of Indonesian workers in various sectors of formal and informal economic activities by establishing clear qualification levels and equivalence with qualifications of other countries in the world. It is undeniable that IQF is the government's effort in realizing quality education in order to produce quality and highly competitive Indonesian human resources. Competence is an accumulation of a person's ability to carry out a measurable work description through a structured assessment, covering aspects of independence and individual responsibility in the field of work. The learning outcome according to IQF is an internalization and accumulation of knowledge. In addition, skills, attitudes, and competencies are achieved through a structured educational process that covers a particular field of expertise / expertise or through work experience. The existence of this IQF is expected to change the way of looking at one's competence, no longer merely a diploma but by looking at a qualification framework that is nationally agreed upon as the basis for recognizing one's educational outcomes broadly (formal, non-formal, or in formal) that is accountable and transparent.

The general purpose of this research is to obtain methods / models of learning that are effective and efficient. So that it can improve the quality of learning and competencies of higher education graduates, in accordance with the needs of stakeholders in the job market. In addition, it is also to increase the competitiveness of graduates, so that they are able to compete in the world of work on a global and international scale.

This study examines the quality of private higher education's learning in Indonesia mediated by professionalism of lecturers as well as facilities and learning media. Next is reviewing the competencies of private higher education's graduates that are moderated by learning outcomes and IQF-based curriculum, so that the quality of private higher education's outcomes (graduates) will also improve. Finally, it examines the absorption of private higher education's graduates in the job market mediated by diploma supplement and networking. This phenomenon is very interesting to be studied in depth as a contribution of researchers in the development of human resources through higher education.

\section{Literature Review}

\subsection{Graduates Competencies}

Competence is an accumulation of a person's ability to carry out a measurable work description through a structured assessment, covering aspects of independence and individual responsibility in the field of work. The learning outcome according to IQF (Indonesian National Qualification Framework), is an internalization and accumulation of knowledge, skills, attitudes, and competencies achieved through a structured educational process that covers a particular field of science / expertise or through work experience. The existence of this IQF is expected to change the way of looking at one's competence, no longer merely a diploma but by looking at a qualification framework that is agreed on nationally as a basis for recognition of one's educational outcomes broadly (formal, non-formal, or in formal) that are accountable and transparent.

This IQF-based curriculum emphasizes the importance of Learning Outcome as a determinant of the graduate profile of a tertiary institution. Thus, it is important to map Learning Outcomes that affect the quality and competitiveness of tertiary graduates, so that they can be improved to respond to the needs of stakeholders. Higher Education can develop their respective curriculum by referring to the National Higher Education Standards for each Study Program which includes the development of intellectual intelligence, noble morals, and skills. However, every university can develop the character of existing institutions and study programs as a factor of attraction for students, students and stakeholders (Suparwati, Trisnaningsih, \& Suratnoaji, 2015). Normatively, there are directions for learning outcomes. However, the implementation of learning achievements in order to meet the expectations of the stakeholders (stakeholders) still seems to need a deeper study. The competition among higher education institutions in Riau Province and other countries, such as Vietnam very tight and intense, it pushes universities and colleges to keep improving their service 
quality in order to meet the market demands (Cheng, 1996; Le, 2019).

\subsubsection{Learning Outcome}

Learning Outcome is the internalization and accumulation of knowledge, attitudes, skills and competencies achieved through a structured educational process that covers a particular field of expertise / expertise or through work experience (Murtiani, 2013). Education unit level curriculum for each study program in higher education is developed and determined by each tertiary institution with reference to the National Higher Education Standards (SN-DIKTI).

Level learning achievements in IQF (Permendikbud RI No.73, 2013), namely:

Able to apply their field of expertise and utilize science, technology, and / or art in their fields in problem solving and be able to adapt to the situation at hand (Work Ability)

Mastering theoretical conceprivate higher education in certain general knowledge fields and conceprivate higher education theoretical special section in the field of knowledge in depth, and be able to formulate procedural problem solving (Knowledge Mastery)

Able to take appropriate decisions based on analysis of information and data, and be able to provide guidance in choosing various alternative solutions independently and in groups (Attitudes and Values)

Responsible for one's own work and can be given responsibility for the achievement of the work of the organization (Authority and Responsibility).

\section{Social Networking (Networking)}

In the current global and digital era, information and communication technology (ICT), and social networking (networking) have a significant influence in the development of various sectors, including in the field of education. The use of information and communication technology and networking is very beneficial to create a more conducive learning process. ICT-based learning (elearning) enables students to find their own way of learning and be more motivating in learning. Besides that, the development of E-learning Management System (ELMS) by using Moodle System or others can be utilized by lecturers more optimally for networking. E-learning can be done in full or blended or hybrid (Rifandi, 2013).

\subsection{Graduates Competence Affects the Uptake of Higher Education Graduates in the Job Market}

IQF is a competency qualification skeleton framework which juxtaposes, equalizes, and integrates the fields of education and job training. In addition, work experience in the context of providing work competence recognition in accordance with the work structure in various sectors. At this time IQF has become the basis for curriculum development in higher education and its implementation in the teaching and learning process. But the effectiveness of the implementation and the results show different performance, so it is interesting to conduct further studies.

Learning Outcome is the profile of graduates of an educational institution. Besides that, it is also an expression of what students know, understand, and can do when they learn, which is a competency that must be achieved by students. To get quality learning outcomes, the implementation of education must be effective and efficient starting from educational institutions, curriculum, teaching and learning process to management of education management. Cheng (1996) states: "School effectiveness as the capacity on the school to maximize school functions or the degree to which the school can perform school functions, when given a fixed amount of school input". He associated five characteristics with effective schools which include strong leadership by the principal, high expectations of student performance, emphasis on basic skills, orderly and controlled atmosphere, and frequent testing of student performance. Based on the study of the theory above and the logic of thinking, then the hypothesis can be formulated as follows:

$\mathbf{H}_{1}$ : Graduates competence directly influences the uptake of higher education graduates in the job market

\subsection{Diploma Supplement and Social Networking}

Etymologically, the competitiveness of graduates can be interpreted as the abilities needed to do or carry out work that is based on knowledge, attitudes, and work skills. Competence can be interpreted as the ability of someone who can be observed including the knowledge, skills and work attitudes in completing a job or task in accordance with established performance standards.

Competitiveness of graduates can also be interpreted as mastery of a task or skill as well as the attitude and appreciation needed to support one's success in a task and job. Competence is knowledge, skills and abilities related to work, as well as abilities needed for non-routine jobs. Lecturer competencies include communication skills, managerial or leadership skills, the ability to get along or foster relationships, whole or honest personalities, as well as being rich in ideas and creative.

Stakeholder satisfaction is a measure of the company's competitive advantage. Satisfaction itself is a feeling that is felt by someone as a result of a comparison between the actual product achievements received by what is expected by that person. When analogous to companies, universities 
are included in the group of "companies" engaged in services. Services sold by universities are educational services. For private universities, because they are not subsidized by the government, the demand for professionally managing their institutions is very high. Universities in this case are competing to improve their quality starting from the improvement of physical infrastructure, the quality of lecturers and the quality of their services. If this is not done there will be dissatisfaction from stakeholders which in the long run will be a threat to the sustainability of the tertiary institution because it will be abandoned by stakeholders. Stakeholder satisfaction is certainly inseparable from the conditions of personal job satisfaction that exist in these higher education. Job satisfaction is a person's attitude towards work that comes from their perceptions about their work stemming from various aspects of work such as wages, promotion opportunities, supervisors and co-workers. Job satisfaction also comes from work environment factors, supervision style, policies and procedures, work group membership, working conditions and benefits. The main reason for studying job satisfaction is to provide managers with ideas about how to improve employee attitudes. Based on the study of theory and logical thinking, a hypothesis is formulated:

$\mathbf{H}_{2}$ : Diploma Supplement as mediation will increase the uptake of higher education graduates in the job market.

$\mathbf{H}_{3}$ : Networking as mediation will increase the uptake of higher education graduates in the job market.

\section{Research Methods}

As a confirmatory research, causal explanation or relationship between variables studied through hypothesis testing (Singarimbun \& Effendi, 1995). The study population is all private higher education in Indonesia in the area of the Dikti I-XIV Service Institution, with the criteria for a minimum institutional accreditation score of $\mathrm{B}$ and had implemented the IQF curriculum. Random sampling technique is based on clusters, namely West Indonesian private higher education (WIB), Central Indonesian private higher education (WITA), and East Indonesian private higher education (WIT) as sources of data used as samples in this study. The data obtained in the study need to be analyzed in order to draw an appropriate conclusion. Therefore, it is necessary to establish analytical techniques in accordance with the research objectives to be achieved, also to test the truth of the hypothesis (Cooper \& Emory, 1995). Several stages in data analysis, namely: first, to test the validity and reliability testing of the instrument. Validity test is done to ensure that each item in the research instrument is able to measure the variables specified in the study. Each value obtained for each item is correlated with the total value of all items of a variable. Correlation test used was corrected item-total correlation (Santoso, 2006). The reliability test uses Cronbach Alpha $(\alpha)$, where an instrument can be said to be reliable (reliable), if it has a reliability coefficient or Cronbach alpha $\geq 0.6$ (Ghozali, 2007). The next step is analyzing the data using path analysis.

Figure 1 shows the description of the activities to be carried out in a competency-based basic research.

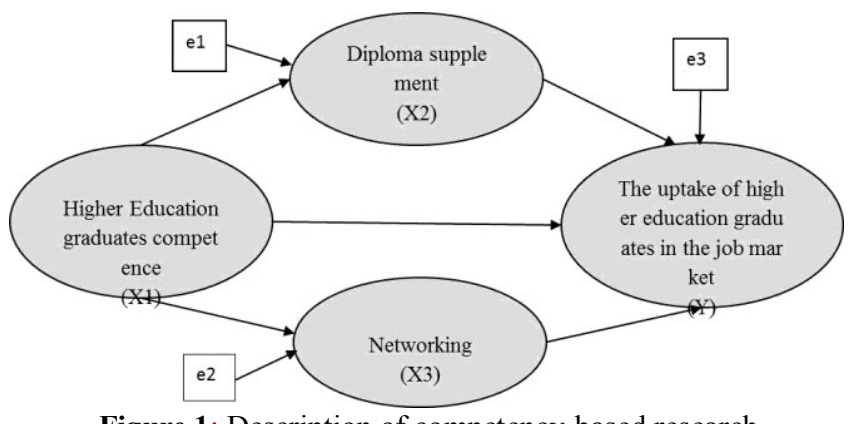

Figure 1: Description of competency-based research implementation activities

\section{Results and Discussion}

\subsection{Overview of Respondents}

This research was conducted by collecting data through sending questionnaires directly by the research team, via courier, or via postal service to respondents. Questionnaire submission is carried out on (the fourth week) of April 2019, and return is expected two weeks after the questionnaire is received by the respondent. The data collection process is carried out for approximately four weeks (one month), which is until the end of May 2019. Of the 795 questionnaires sent to respondents, 279 returned with a response rate of $35.09 \%$. Of the 279 returned questionnaires, there were 117 questionnaires that could be analyzed. Whereas 162 questionnaires could not be analyzed because the respondent only answered a part of the questionnaire.

The construct validity in this study was tested using corrected item-total correlation, that is, by correlating the total score with the score obtained on each question item. With the number of respondents $\mathrm{n}=117$ and a significance level of $5 \%$, the questionnaire was declared valid if the correlation coefficient $r$ was more than 0.12 . The correlation coefficient $r$ of the research questionnaire can be seen in the corrected item-total correlation. If an item in the questionnaire is invalid, the item will be deleted. The 
following tables show the validity test results for each research variable. The results of the validity test for the variables of graduate competence, certificate of companion diploma, networking, and absorption of graduates of higher education in the job market, indicate that the instrument items are all variables with a corrected item-total correlation value $>0.12$. Thus all instruments of the research variable are valid.

\subsection{Reliability Test}

Reliability analysis was performed using Cronbach's Alpha coefficient of 0.6 for each questionnaire for each variable. Reliability shows the consistency of the measuring device in measuring the same symptoms. A measuring device is said to be reliable if the Alpha coefficient value is above 0.6 . Reliability testing is carried out after the validity test, which only valid items are included in this test. The results of the validity and reliability test, showed that all variables in this study, namely: Graduates' competencies, Diploma Supplement, networking, and absorption of college graduates in the job market are valid and reliable. This is evidenced by the results of the corrected item-total correlation value $>0.12$ and Alpha coefficient values above $(\alpha \geq 0.6)$.

\subsection{Path Analysis Results}

To find out the relationship between the four research variables, eight hypotheses will be tested. These hypotheses are tested using path analysis. Hypothesis testing using this path analysis to test the effect of each independent variable on the dependent variable. Hypothesis testing with path analysis is based on the results of processing from the research model. The results of data processing in Figure 2 can be seen how much each variable is towards other variables or is called the path coefficient (path coefficient). To see the results of testing the research hypothesis proposed at the beginning of this study, it can be seen in Table 1. below.

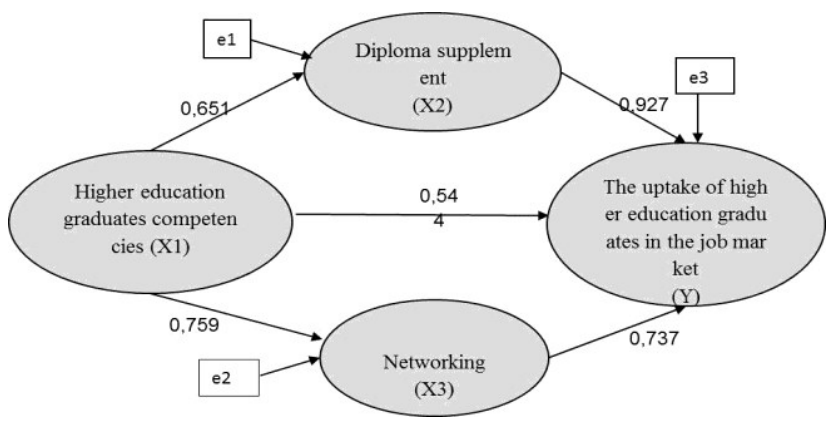

Figure 1: Description of competency-based research implementation activities
Table 1: Regression weights

\begin{tabular}{|c|c|c|c|c|c|c|c|}
\hline & & & Estimate & $\begin{array}{c}\text { Standard } \\
\text { Estimate }\end{array}$ & S.E. & C.R. & P \\
\hline SL & $<--$ & KL & 0,422 & 0,544 & 0,061 & 6,961 & 0,000 \\
\hline SKPI & $<--$ & KL & 0,492 & 0,651 & 0,054 & 9,200 & 0,000 \\
\hline NW & $<--$ & KL & $-0,492$ & 0,759 & 0,054 & 9,200 & 0,000 \\
\hline SL & $<--$ & SKPI & 0,681 & 0,927 & 0,072 & 9,508 & 0.000 \\
\hline SL & $<--$ & Nw & 0,681 & 0,737 & 0,072 & 9,508 & 0.000 \\
\hline
\end{tabular}

\subsection{Hypothesis Testing}

Hypothesis testing can be done by comparing the value of C.R and P value on each relationship between variables with a predetermined significance of 1.96 with a limit of $5 \%$.

The first hypothesis, states that the Graduates' competencies directly influences the uptake of higher education graduates in the job market. In the results of data processing note that the value of C.R. the relationship between graduates' competency variables and the uptake of higher education graduates in the job market is 6.961 with a $\mathrm{P}$ value of 0.000 . With this value, the first hypothesis is accepted, because the value of C.R. and P fulfills the significance requirements of 1.96 and 0.05 . Based on the results of data processing, it can be said that there is a significant influence between the variable Graduates' competencies on the variable absorption of college graduates in the job market.

The second hypothesis, it is stated that the absorption of higher educationgraduates in the job market is indirectly influenced by the Graduates' competencies through SKPI (Diploma Supplement) as mediation. The results of data processing in Table 1. show that the competency of graduates through Diploma Supplement as mediation has an effect of 0.603 on the uptake of higher education graduates in the job market with a significance level of $5 \%$. Thus, it can be said that the second hypothesis is accepted because the indirect effect is greater than the direct effect of the Graduates' competencies on the uptake of college graduates in the job market by 0.544 . graduates against uptake of college graduates in the job market.

The third hypothesis, it is stated that the uptake of higher education graduates in the job market is influenced by graduate competencies indirectly through networking as mediation. The results of data processing in Table 1. show that the competency of graduates through networking as mediation has an effect of 0.559 on uptake of college graduates in the job market with a significance level of 5\%, so it can be said that the third hypothesis is accepted because the indirect effect is greater than the direct effect. Graduates' competencies directly affects the uptake of college graduates in the job market by 0.544 . Thus, it was 
concluded that the networking variable is an intervening variable in the relationship between graduate competencies and the absorption of college graduates in the job market.

\subsection{The Effect Analysis}

At the effect analysis stage, an analysis of the relationship between the independent variables and the dependent variable has been tested significantly. Hypothesis testing results are known that all hypotheses have been proven significantly. Thus, all influence analysis can be done. Table 2 shows the results of the analysis of the effect of the independent variables on the dependent variable.
The indirect effect of graduate competency variables on the uptake of higher education graduates in the job market with a diploma companion certificate as mediation is 0.603 and the indirect effect of graduate competency variables on the uptake of higher education graduates in the job market through networking is 0.559 . The direct effect of graduate competency variables on uptake of college graduates in the job market is 0.544. The indirect effect of graduate competence on the the uptake of higher education graduates in the job market through SKPI and networking has a greater influence, namely 0.603 and 0.559 compared to the direct influence of 0.544. Thus, the Diploma Supplement and networking functions as an intervening variable.

Table 2: The Effects Analysis

\begin{tabular}{|c|c|c|c|c|c|c|c|c|c|}
\hline & \multicolumn{3}{|c|}{$\begin{array}{c}\text { Standardized } \\
\text { Direct Effect }\end{array}$} & \multicolumn{3}{c|}{$\begin{array}{c}\text { Standardized } \\
\text { Indirect effect }\end{array}$} & \multicolumn{3}{c|}{$\begin{array}{c}\text { Standardized } \\
\text { Total Effect }\end{array}$} \\
\hline & $\mathrm{KL}$ & $\mathrm{SKPI}$ & $\mathrm{Nw}$ & $\mathrm{KL}$ & $\mathrm{KL}$ & $\mathrm{KL}$ & $\mathrm{KL}$ & $\mathrm{SKPI}$ & $\mathrm{Nw}$ \\
\hline $\mathrm{SKPI}$ & 0,651 & 0,000 & 0,000 & 0,000 & 0,000 & 0,000 & 0,000 & 0,000 & 0,651 \\
\hline $\mathrm{Nw}$ & 0,759 & 0,000 & 0,000 & 0,000 & 0,000 & 0,000 & 0,000 & 0,000 & 0,759 \\
\hline $\mathrm{SL}$ & 0,544 & 0,927 & 0,737 & 0,603 & 0,559 & 0,000 & 1,147 & 0,927 & 0,737 \\
\hline
\end{tabular}

\subsection{Implications of Research Results}

Based on the results of testing the model is expected to contribute ideas for the lecturers and university leaders. Especially for university leaders, in terms of recruiting new lecturers to pay attention to the quality and competence of the lecturers. Given the lecturers are the spearhead for an institution or institution of higher education.

Some implications that can be proposed are:

1) The results of the model testing show that the Graduates' competencies has a significant effect on uptake of college graduates in the job market. The indirect effect of graduate competency on the uptake of higher education graduates in the job market through a Diploma Supplement and networking has a higher level of influence compared to the direct effect of graduate competency on the uptake of higher education graduates in the job market. This indicates that the Diploma Supplement and networking can increase the uptake of higher education graduates in the job market. Trisnaningsih, Suparwati, Sutrisno, and Permatasari (2018), that the quality of learning has a significant direct effect on the Graduates' competencies. Thus, to improve the Graduates' competencies at higher education, lecturers who are professional and reliable and competent in their fields are needed. Therefore, to improve the quality of learning and improve the quality of graduate outcomes that are reliable and competent in their fields, it takes qualified lecturers who are committed to their profession. In line with the results of previous studies, states that the performance of qualified lecturers and committed to their profession as lecturers can improve the outcomes of graduates who are qualified and competent in their fields (Trisnaningsih, 2013a).

2) Lecturers have a significant influence in the formation of quality human resources in cognitive, affective and psychomotor aspects. Lecturers are one of the quality guarantors in the education process who are professional educational staff who are required to have competence so that they can realize quality performance standards. Furthermore, it is expected to lead to improving the quality of higher education organizational performance and impacting on the quality of education or the quality of graduates. Trisnaningsih (2013b) states that lecturers who have high motivation to their institutions, the lecturers' performance will get better and better quality. Thus lecturers are the spearhead in a tertiary institution, because they are very influential on the quality of the outcomes of graduates produced. Therefore, a university must be able to produce graduates that are reliable and of high quality and noble, so that it can provide hope and satisfaction to its users (stakeholders).

3) In accordance with Permendikbud Republik Indonesia No.49 (2014). It is stated that the competency standard of high school graduates at the higher education level aims to 
prepare students to become noble members of society, possessing knowledge, skills, independence, and attitudes to discover, develop, and apply knowledge, technology and arts that benefit society. Thus, graduate competency is a qualification of graduates' abilities that includes attitudes, knowledge, and skills in accordance with agreed national standards. This is in line with the expectations of the stakeholders.

\section{Conclusions}

The results of the data analysis showed that the Graduates' competencies had a significant effect on the uptake of higher education graduates in the global market. This shows that the leaders of higher education institutions must provide motivation to their lecturers so that their performance becomes better and optimal. The lecturers who are committed and loyal to their institutions must have high motivation to be able to become better and outstanding lecturers. Professional and accomplished lecturers will increase oucome of college graduates according to their field of competence.

In addition, the results of this study also stated that the Diploma Supplement and networking had a higher level of influence compared to the direct influence of graduate competencies on the uptake of college graduates' outcomes in the job market. This indicates that the Diploma Supplement and networking can increase the uptake of higher education graduates in the local and international job market. The professionalism of lecturers has a significant influence on the quality of learning. Thus, it can be concluded that lecturers of higher education should improve the quality of their human resources. Besides that, they must also have high loyalty to their institutions so that the performance of the lecturers will be better, optimal and able to compete in the era of globalization.

\section{References}

Cheng, Y. C. (1996). School Effectiveness and School-based Management: A Mechanism for Development. School Effectiveness and School Improvement, 7, 35-61.

Cooper, D. R., \& Emory, C. W. (1995). Business Research $\operatorname{Method}\left(5^{\text {th }}\right.$ Ed). Chicago, IL: Irwin.
Le, N. T. D., \& Nguyen, N. D. P. (2018). Organizational Justice, Job Satisfaction and Organizational Citizenship Behavior in Higher Education Institutions: A Research Proposition in Vietnam. Journal of Asian Finance, Economics and Business, 5(3), 113-119. http://doi.org/10.13106/jafeb.2018.vol5.no3.113

Ghozali, I. (2007). The Implementation of Multivariate Analysis using SPSS Software. Indonesia: Universitas Diponegoro Semarang.

Kumari, N. (2014). Most to Least Preferred Parameters Affecting the Quality of Education: Faculty Perspectives in India. Journal of Asian Finance, Economics and Business, 1(3), 3742. https://doi.org/10.13106/jafeb.2014.vol1.no3.37.

Le, Q. H. (2019). Factors Affecting Brand Values of Private Universities: A Case Study of Ho Chi Minh City University of Technology (HUTECH). Journal of Asian Finance, Economics and Business, 6(1), 159-167. http://doi.org/10.13106/jafeb.2019.vol6.no1.159

Murtiani, F. (2013). Enhancing Learning Achievement in Computer Subjects in Physics Learning Through the Implementation of the 5E Learning Cycle Model. Jurnal Eksakta, 2, Tahun XIV.

Permendikbud Republik Indonesia No.73. (2013). Implementation of the Indonesian National Qualification Framework in Higher Education.

Permendikbud Republik Indonesia No.49. (2014). National Standards of Higher Education.

Rifandi, A. (2013). Learning Quality and Competence of Polytechnic Diploma III Graduates. Cakrawala Pendidikan, Tahun XXXII, No.1

Santoso, S. (2006). Business Research Methods. Indonesia: CV. Alfabeta Bandung.

Singarimbun, M., \& Effendi, S. (1995). Survey Research Methods ( $2^{\text {nd }}$ ed.). Indonesia: PT. Pustaka LP3ES Indonesia.

Suparwati, Trisnaningsih, S., \& Suratnoaji, C., (2015). Organizational and Professional Commitment as Mediation to Improve Stakeholders Satisfaction. International Journal of Academic Research, 7(2), 39-43.

Trisnaningsih, S. (2013a). Contingency Model to Improve Lecturers Performance with Motivation as an Intervening variable. International Journal of Academic Research, 5(1), 54-59.

Trisnaningsih, S., (2013b). Motivation and Commitment as Contingencies to Improve Graduate Competency. International Journal of Academic Research, 5(6), 270-274.

Trisnaningsih, S., Suparwati, Sutrisno, \& Permatasari, Y. (2018). Indonesian Qualification Framework (IQF)-Based Curriculum as A Contingency Model to Improve Graduates Competencies. International Journal of Mechanical Engineering and Technology, 9(9), 359-366. 